\title{
The Relationship between Practicing Knowledge Management Processes and the Effectiveness of Administrative Decisions Made by Schools' Principals in Ma'an Governorate
}

\author{
Dima M. Waswas ${ }^{1}$, Moh'd Kh. Abu AL Rob ${ }^{1}$ \& Osama M. Kraishan ${ }^{1}$ \\ ${ }^{1}$ Department of Curriculum and Teaching, Al Hussein Bin Talal University, Ma'an, Jordan \\ Correspondence: Moh'd Kh. Abu AL Rob, Department of Curriculum and Teaching, Al Hussein Bin Talal \\ University, Ma'an, Jordan. E-mail: mohd_aboalrob@yahoo.com
}

Received: March 17, 2016

Accepted: February 5, 2017

Online Published: March 20, 2017

doi:10.5539/jedp.v7n1p249

URL: http://doi.org/10.5539/jedp.v7n1p249

\begin{abstract}
This study aims at determining the level of practicing knowledge management processes and the effectiveness level of administrative decisions made by the schools' principals in Ma'an Governorate, as well as determining the nature of the relationship between practicing knowledge management processes and the effectiveness level of making administrative decisions. A sample consisting of 120 school principals was randomly chosen.

The study found that the levels of practicing knowledge management by the school principals in Ma'an Governorate were all high and ranged between 4.28-4.52. The results also showed that the arithmetic means for the effectiveness level of the administrative decisions made by school principals in Ma'an Governorate ranged between 4.33-4.75 with high practicing level. Moreover, there is a statistically significant relationship between the effectiveness level of administrative decision-making on the one hand and the fields of knowledge management processes on the other hand. There are also statistically significant differences between the arithmetic means of the (High Diploma) estimates on the one hand, and the arithmetic means of the (Bachelor degree) estimates on the other hand, regarding the field "transferring and using knowledge" in favor of the (High Diploma). The same goes for the (Bachelor degree) estimates on the one hand, and the (Master degree) estimates on the other hand in favor of the (Master degree).
\end{abstract}

Keywords: administrative decisions, knowledge management processes, schools principals

\section{Introduction}

Interest in knowledge management came as a result of several factors: first, the rapid IT developments, which made the exchange of knowledge faster and easier through connecting individuals by electronic networks to help them exchange information and experiences. Second, the striving by the organizations to become learning organizations in which managers seek a particular organizational culture that meets the requirements of finding, providing and exchanging knowledge in the appropriate time and place. Since then, the term "knowledge management" emerged to represent a radical shift in the nature of modern organizations work in terms of the attention given to the human element who is the main permanent producer and interactor with modern technology systems and tools. It was found that the best corporate results can only be achieved through humans who work and interact continuously with it to choose the best procedures and applications (Hansen, 1990).

York (2005) indicates that the human capital is the employee's competency: his capacity inside the organization. This competency is linked to the employees' presence in the organization. If the employees leave the organization temporarily or permanently, the organization loses this competency. The importance of competency increases with the increase in the information and knowledge that the employees posses about their organization. An organization should make use of its employees' competency through establishing positive environment that allows the employees to transfer their information; and through giving the employees the impression that they are reliable and trustworthy.

We can say that the historical roots of knowledge management started since the appearance of scientific management, the most famous pioneers of which were Taylor and Fayol, who laid the basic foundations of scientific management (Arab Forum for Human Resource Management, 2015). A number of management 
theorists contributed to the emergence and development of knowledge management, including Peter Drucker and Paul Strassman who stressed the growing importance of explicit information and knowledge as regulatory resources (Al-Thbaity, 2002).

In the mid-nineties, knowledge management initiatives flourished by virtue of the Internet. There was a growing interest in knowledge management especially after many organizations adopted the concept of knowledge management. In 1999 the World Bank allocated 4\% of the budget for the development of knowledge management systems (York, 2005).

As a result of the growing interest in studies conducted on the concept of knowledge management, there was no consensus among researchers on a specific concept of knowledge management, which led to the emergence of several definitions of knowledge management, including:

- The systematic and organized process of establishing and using knowledge which requires converting personal knowledge to collaborative knowledge that can be clearly shared through the organization (Al-Kubaisi., 2004, p. 48)

- Converting intellectual assets to work value (Zerger, 1998, p. 16)

- The systematic collection, analyzation and interpretation of information from sources inside and outside the organization, then inferring indicators in order to guide and enrich the processes in the organization; and to achieve improvement in performance and elevating achievement to higher levels (Al-Sawi, 2007, p. 22).

Accordingly, we can define Knowledge Management as: the process of discovering, storing, restoring, distributing and using information, whether that information is implicit or explicit.

Knowledge management consists of several operations, as follows (Al-Ali, 2006):

1) Diagnosing knowledge: this phase begins with defining knowledge; then, searching for knowledge; next, comparing the existing knowledge with the required knowledge.

2) Acquiring knowledge: represents the stage of obtaining knowledge from various internal or external references and sources.

3) Storing knowledge: the process of storing knowledge is considered a bridge linking the process of collecting knowledge and the process of restoring knowledge to meet the opportunities of change in the future.

4) Developing and distributing knowledge: the development of knowledge occurs through increasing the capacity, the skills, and the competencies of employees regarding knowledge.

5) Using knowledge: using knowledge is more important than knowledge itself; the goal and purpose of knowledge management is making use of knowledge available to the organization.

Knowledge management gains its importance through the targets that it seeks to achieve. These targets are manifested by: generating the necessary and sufficient knowledge to carry out the cognitive transformation processes and disseminate knowledge to all relevant parties; developing and updating knowledge continuously; determining the nature of intellectual capital that is required for the organization and determining how to develop and maintain it; controlling and monitoring the processes relevant to knowledge management; and seeking effective leadership capable of building and practicing knowledge management (Holsapple \& Singh, 2001).

Wang (2006) pointed out that the relationship between knowledge employment and decision-making is exemplified in the support provided to the decision maker in all levels of management by linking personal decisions with the computerized information. This provides support in all stages of the decision-making process, as it enables the decision maker to solve very complex issues and achieve integration between databases, information systems and the Internet.

The administrative decision is the backbone of management and the decision-making process is one of the basic functions of managers. It is an intellectual process that seeks to choose the most appropriate alternative from several alternatives by means of differentiation between them using standards that are suitable for the internal and external conditions facing the decision maker. Actually, the decision and decision-making are a reflection of a behavior that will occur in the future and the expected results this behavior will have (Al-Aqili, 2005).

The multiplicity and complexity of the organization's goals, and sometimes the existence of conflict between these goals increased the importance of the decisions in the educational administration. The organization no longer seeks to achieve one goal as it was before, but it has to seek to achieve a number of complex and interrelated goals, which requires choosing a lot of decisions to face these problems (Al-Naji, 2011). 
Educational institutions guarantee a good life quality for students and personnel through education. This includes participating in an educational system based on a strong foundation of knowledge. It also includes responsibilities for the development of school work and educational services provided for students. Despite the clarity of such issues in the field of education, there were no real opportunities to address these issues through systematic approaches. Hence, came the importance of knowledge management in providing new opinions, ideas, and effective practices to ensure the distinction and quality of educational administration. This places a new responsibility upon the administration; that is, managing organizational knowledge in educational institutions (Beblawi \& Hussein, 2007).

\section{Literature Review}

Newton (2004) conducted a study entitled "Knowledge Management in School Boards". The study aimed at examining knowledge management such as (knowledge database, transferring and processing knowledge) in the departments of education, and the ability to manage knowledge in these departments when facing difficult decisions that must be taken. The study found that there are differences in the databases used by the department of education and the school administration. Those differences appeared in the knowledge itself and its management, and in the activities used in creativity.

The study of (Keeley, 2004) entitled "The Effectiveness of Knowledge Management in the Development of Planning and Decision-making in Higher Education Types" showed a high correlation between the effective institutional and organizational teaching, and the presence of an effective formal program for knowledge management. Moreover, the study revealed that practicing knowledge management by the institutions of higher education through research commissions was moderate. The results also showed that the higher education institutions which provided infrastructures of systems and devices that support knowledge doubled the chances of individuals in knowledge participation.

Glickman study (2004) entitled "What Counts: Education Knowledge Management Practices" aimed at examining the concept of knowledge management in pioneer schools in North Vancouver as exemplified by their practices related to generating, capturing, and disseminating "Knowledge" and promoting informed professionalism. The study indicated that educators found it difficult to foster a culture of collaboration and interaction within and across schools or among teachers; and, they also found it difficult to systematically manage their working knowledge.

Tashkandi study (2006) aimed to explain the importance of employing knowledge management in education administration; and to determine the most important processes of knowledge management and practices that make it active. The study also aimed at studying and analyzing the present situation of knowledge management in education directorates. The results showed that the members of the (study society) know well the importance of knowledge management; and the importance of using knowledge management in education administration.

Al-Khalili Study (2006) entitled "Knowledge Management in the Ministry of Education: An Analytical Study", which aimed to get to know the status of knowledge management at the Ministry of Education in Jordan. The study found that the Ministry of Education was able to consolidate the concept of knowledge management through practicing the activities contained in this concept. The results were high with the exception of storing, disseminating and exchanging of knowledge that showed a medium degree.

Muawiya Study (2008) entitled "Knowledge and Information Management in Higher Education Institutions: International Experiences". The study aimed to shed light on some of the global models of knowledge management and information systems in higher education institutions; and to highlight some of these models that can be adopted by higher education institutions in Jordan in particular, and the Arab world in general. The study found models including virtual, investment and productive higher education institutions that have managed to achieve many successes through the availability of technological environment and infrastructure for knowledge management.

\section{The Problem of the Study}

Knowledge management represents a fundamental shift in the nature of the work of modern organizations, in terms of interest in the human element which is the main, permanent interacting element with modern technology systems and tools. It was found that the best corporate results can only be achieved through the human who interacts continuously to choose the best procedures and applications. Educational institutions in which the human is the fundamental centerpiece of knowledge are considered one of the main pillars of the development of society, as the educational systems are a source of information and knowledge. 
Al-Taweel (2006) indicates that if the transition to knowledge management in the economic and industrial organizations has become a necessity in the age of information and technology, it becomes more urgent in the educational institutions. Such institutions ensure knowledge generation, dissemination and application for today's organizations to assist in administrative decision-making, encourage innovation, increase competitiveness, and to achieve the strategic goals of these organizations.

\section{Questions of the Study}

This study seeks to answer the following questions:

1) What is the level of practicing knowledge management by school principals in Ma'an Governorate?

2) What is the effectiveness level of administrative decisions made by school principals in Ma'an Governorate?

3) Is there a statistically significant relationship at the level $(\alpha=0.05)$ between the arithmetic means of the study sample estimations regarding practicing knowledge management by school principals in Ma'an Governorate and their estimations regarding the effectiveness of administrative decisions made by the principals?

4) Are there any statistically significant differences at the level $(\alpha=0.05)$ between the arithmetic means of the study sample estimations regarding practicing knowledge management by school principals in Ma'an Governorate attributed to the variables (gender, educational qualification, and administrative experience)?

5) Are there any statistically significant differences at the level $(\alpha=0.05)$ between the arithmetic means of the study sample estimations regarding the effectiveness of administrative decisions made by school principals in Ma'an Governorate attributed to the variables (gender, educational qualification, and administrative experience)?

\section{Targets of the Study}

This study seeks to achieve the following targets:

1) Determining the level of practicing knowledge management by school principals in Ma'an Governorate.

2) Determining the effectiveness level of the administrative decisions made by school principals in Ma'an Governorate.

3) Determining the nature of the relationship between practicing knowledge management and the effectiveness level of the administrative decisions made by school principals in Ma'an Governorate.

4) Determining the sources of differences between the responses of school principals in Ma'an Governorate regarding the level of practicing knowledge management and the effectiveness level of the administrative decisions.

\section{The Importance of the Study}

The importance of the study is shown in a number of points, namely:

- The importance of knowledge management which is an administrative approach aims at gathering, arranging, organizing and disseminating knowledge; in order to improve the efficiency of school administration.

- Linking knowledge management with the processes of making administrative decisions, which is a fundamental pillar of administrative work.

- The benefits that the school principals in Ma'an Governorate gain from the results of this study through determining the level of practicing knowledge management and the effectiveness level of administrative decision-making. It is possible that the results serve as a catalyst for the development of knowledge management in schools and for employing it in administrative decision-making processes.

- This study provides a set of recommendations that can contribute to the activation of practicing knowledge management and its role in administrative decision-making processes.

\section{The Study Limits}

- This study was limited to determining the level of practicing knowledge management; the effectiveness level of the administrative decision-making processes; and determining the relationship between them.

- This study was conducted during the second semester 2014/2015. 
- This study was limited to the school principals in Ma'an Governorate which includes the directorates of education in Ma' an, Petra, Al-Shoubak, and Southern Badia.

\section{The Study Terms}

The procedural definitions for the main terms of the study:

The processes of knowledge of management: a set of processes employed by the school administration to maximize the intellectual capital efficiency, these processes include: the level of knowledge acquisition and development; the level of organizing and assessing knowledge; and transferring and using knowledge.

The effectiveness of administrative decision-making: organized processes employed by school administration to handle all situations and problems during work by providing enough information; seeking suitable alternatives and choosing the most suitable one, for the sake of achieving the required target according to the issue and its conditions.

\section{Methodology and Procedures}

\subsection{The Study Method}

To achieve the targets of the study, the correlation method was used to determine whether there is a relationship between practicing the processes of knowledge management and the process of making administrative decisions; and then determining the level of that relationship. A questionnaire based on the theoretical literature and the previous studies was prepared for this purpose. The questionnaire was distributed to the study sample (school managers in Ma'an Govornorate); then, the respondents' data was analyzed using the SPSS statistics.

\subsection{The Study Population}

The study population included all school principals in Ma'an Governorate, totaling 189 principals, during the academic year 2014/2015.

\subsection{The Study Sample}

The study sample was randomly selected from the study population. The sample consisted of 120 school principals in Ma'an governorate which made up $63 \%$ of the study population. Table 1 shows the distribution of the study sample according to the study variables, namely: gender, education level, and years of experience in administration.

Table 1. Distribution of the study sample according to the variables: gender, education level, years of experience in administration

\begin{tabular}{llcc}
\hline \multicolumn{1}{c}{ Variable } & Level & Number & Percentage \\
\hline Gender & Male & 40 & 33.3 \\
& Female & 80 & 66.7 \\
\hline Education level & Diploma & 6 & 5.0 \\
& Bachelor degree & 28 & 23.3 \\
& High diploma & 66 & 55.0 \\
& Master degree & 18 & 15.0 \\
& Doctorate degree & 2 & 1.7 \\
\hline Years of experience in administration & Less than 5 years & 28 & 23.3 \\
& From 5-10 years & 41 & 34.2 \\
& More than 10 years & 51 & 42.5 \\
\hline & Sub total & 120 & 100.0 \\
\hline
\end{tabular}

\subsection{The Study Tool}

A questionnaire was designed to determine the level of knowledge management and its relationship with the effectiveness level of the administrative decisions made by the school principals in Ma'an Governorate. The questionnaire included 37 items, and consisted of two main domains. The first domain to measure the level of 
practicing knowledge management covering three fields, namely: the level of knowledge acquisition and development; the level of organizing and assessing knowledge; and the level of transferring and using knowledge. The second domain for measuring the effectiveness of administrative decision-making.

\subsection{The Validity of the Study Tool}

To determine the validity of the study tool, it was presented to 10 specialized, expert evaluators from the faculty members in the College of Education at Al-Hussein Bin Talal University. In light of the observations and recommendations of the evaluators, some linguistic amendments were made to some of the questionnaire items.

\subsection{The Reliability of the Study Tool}

To ensure the reliability of the study tool, the Cronbach's Alpha equation was used on the original sample of the study, to determine the stability of the internal consistency of the instrument as a whole. The reliability coefficient was 94.0 which is a high enough value to conduct the study.

\subsection{Scoring the Questionnaire}

A Likert-type scale was used as follows: always, often, sometimes, rarely, never and the following numerical values 5, 4, 3,2,1 were given respectively to evaluate the relationship of practicing knowledge management with the effectiveness of administrative decisions made by school principals in Ma'an governorate. The following statistical was used for the distribution of the arithmetic means:

First: $\quad(1.00-2.49)$ low evaluation degree

Second: $\quad(2.50-3.49)$ medium evaluation degree

Third: $\quad(3.50-5.00)$ high evaluation degree

\subsection{Statistical Procedures}

The following statistical procedures were used: arithmetic means, standard deviations, Pearson's Correlation Coefficient, Multivariate Analysis of Variance (MANOVA), and Scheffe's Test.

\subsection{The Study Results and Discussion}

To answer the first question: What is the level of practicing knowledge management by school principals in Ma'an Governorate? The arithmetic means and standard deviations of the respondents' estimates for each item of the scale, and for the scale as a whole, were calculated as described in the Tables 2-5.

Table 2. The arithmetic means and standard deviations for each item of the scale and for the scale as a whole in descending order (according to arithmetic means)

\begin{tabular}{ccccc}
\hline No. & field & $\begin{array}{c}\text { Arithmetic } \\
\text { Mean }\end{array}$ & $\begin{array}{c}\text { Standard } \\
\text { Deviation }\end{array}$ & $\begin{array}{c}\text { Agreement } \\
\text { Degree }\end{array}$ \\
\hline 3 & transferring and using knowledge & 4.52 & 0.41 & High \\
1 & knowledge acquisition and development & 4.29 & 0.40 & High \\
2 & organizing and assessing knowledge & 4.28 & 0.47 & High \\
& Levels as a whole & 4.34 & 0.37 & High \\
\hline
\end{tabular}

*The highest value is 5 .

Table 2 shows that the arithmetic means of the scale fields ranged from 4.28-4.52. The highest mean value was for the field of "transferring and using knowledge" with a standard deviation 0.41 and a high evaluation degree. The field of "knowledge acquisition and development" came next with a mean of 4.29 and a standard deviation of 0.40 and a high evaluation degree. The lowest mean value was for the field "organizing and assessing knowledge" with a standard deviation of 0.47 and a high evaluation degree. The arithmetic mean for the fields as a whole was 4.34 with a standard deviation 0.37 and a moderate evaluation degree. 
Table 3. The arithmetic means and standard deviations for the respondents' estimates regarding the field:

"knowledge acquisition and development" in descending order

\begin{tabular}{|c|c|c|c|c|}
\hline No. & Item & $\begin{array}{l}\text { Arithmetic } \\
\text { Mean* }\end{array}$ & $\begin{array}{l}\text { Standard } \\
\text { Deviation }\end{array}$ & $\begin{array}{c}\text { Agreement } \\
\text { degree }\end{array}$ \\
\hline 9 & $\begin{array}{l}\text { I make sure to inform all school staff of knowledge } \\
\text { developments }\end{array}$ & 4.55 & 0.63 & High \\
\hline 5 & I seek new methods of administrative work & 4.53 & 0.59 & High \\
\hline 11 & I develop knowledge of all school staff & 4.40 & 0.60 & High \\
\hline 10 & $\begin{array}{l}\text { I provide mechanisms to receive all opinions and } \\
\text { suggestions from school staff }\end{array}$ & 4.39 & 0.64 & High \\
\hline 1 & $\begin{array}{l}\text { Knowledge transfers from one person to another } \\
\text { within the school }\end{array}$ & 4.35 & 0.64 & High \\
\hline 6 & $\begin{array}{l}\text { I work on bringing knowledge from outside the } \\
\text { school }\end{array}$ & 4.33 & 0.66 & High \\
\hline 7 & $\begin{array}{l}\text { I announce the best knowledge resources available } \\
\text { within the school available }\end{array}$ & 4.29 & 0.76 & High \\
\hline 2 & I identify the knowledge resources within the school & 4.22 & 0.66 & High \\
\hline 4 & $\begin{array}{l}\text { I identify the ways of storing knowledge within the } \\
\text { school }\end{array}$ & 4.22 & 0.67 & High \\
\hline 3 & I transfer new knowledge into value & 4.12 & 0.70 & High \\
\hline 8 & I transfer implicit knowledge into public knowledge & 4.08 & 0.75 & High \\
\hline \multirow[t]{2}{*}{12} & $\begin{array}{l}\text { I provide supportive organizational culture for } \\
\text { research and development within the school }\end{array}$ & 4.03 & 0.76 & High \\
\hline & The field as a whole & 4.29 & 0.40 & High \\
\hline
\end{tabular}

*The highest value is 5 .

Table 3 shows that the arithmetic means for the items of the field "knowledge acquisition and development" ranged between 4.03-4.55. The highest value was for item number 9, "I make sure to inform all school staff of knowledge developments" with a standard deviation 0.63. Item number 5 "I seek new methods of administrative work" came second with arithmetic mean of 4.53 with a standard deviation 0.59 . The lowest arithmetic mean value was for item number 12 "I provide supportive organizational culture for research and development within the school" with a standard deviation 0.67. All items came with high evaluation degree.

Table 4. The arithmetic means and standard deviations for the respondents' estimates regarding the field: "organizing and assessing knowledge" in descending order

\begin{tabular}{|c|c|c|c|c|}
\hline No. & Item & $\begin{array}{l}\text { Arithmetic } \\
\text { Mean* }\end{array}$ & $\begin{array}{l}\text { Standard } \\
\text { Deviation }\end{array}$ & $\begin{array}{l}\text { Agreement } \\
\text { degree }\end{array}$ \\
\hline 9 & $\begin{array}{l}\text { I evaluate the performance of the employees according to their } \\
\text { participation in the knowledge management processes. }\end{array}$ & 4.50 & 0.66 & High \\
\hline 3 & $\begin{array}{l}\text { I store knowledge in a way that makes it easy to be accessed; for } \\
\text { example, computerizing data. }\end{array}$ & 4.46 & 0.67 & High \\
\hline 6 & I frequently update data to insure sustained successful work. & 4.45 & 0.62 & High \\
\hline 7 & I review the available knowledge in light of the status quo. & 4.34 & 0.67 & High \\
\hline 2 & $\begin{array}{l}\text { I categorize knowledge in two main categories; one for the teachers, } \\
\text { and the other for the students. }\end{array}$ & 4.28 & 0.72 & High \\
\hline
\end{tabular}




\begin{tabular}{|c|c|c|c|c|}
\hline 5 & I evaluate the validity of the documents used in school activities. & 4.27 & 0.68 & High \\
\hline 1 & I classify data using special techniques assigned to that purpose. & 4.13 & 0.62 & High \\
\hline 8 & I provide explanation to the available knowledge. & 4.09 & 0.74 & High \\
\hline \multirow[t]{2}{*}{4} & I provide a manual (guide) for accessing knowledge. & 4.07 & 0.78 & High \\
\hline & The field as a whole & 2.28 & 0.47 & High \\
\hline
\end{tabular}

*The highest value is 5 .

Table 4 shows that the arithmetic means for the items of the field "organizing and assessing knowledge" ranged between 4.07-4.50. The highest value was for item number 9 "I evaluate the performance of the employees according to their participation in the knowledge management processes", with a standard deviation $(0.66)$. Item number 3 "I store knowledge in a way that makes it easy to be accessed; for example, computerizing data" came second with arithmetic mean of 4.46 with a standard deviation 0.67 . The lowest arithmetic mean value was for item number 4 "I provide a manual (guide) for accessing knowledge" with a standard deviation 0.78 .

Table 5. The arithmetic means and standard deviations for the respondents' estimates regarding the field: "transferring and using knowledge" in descending order

\begin{tabular}{|c|c|c|c|c|}
\hline No. & Item & $\begin{array}{c}\text { Arithmetic } \\
\text { Mean* }\end{array}$ & $\begin{array}{l}\text { Standard } \\
\text { Deviation }\end{array}$ & $\begin{array}{c}\text { Agreement } \\
\text { degree }\end{array}$ \\
\hline 1 & I provide knowledge for all staff working in the school & 4.75 & 0.47 & High \\
\hline 2 & I provide a supportive climate for exchanging knowledge among school staff & 4.67 & 0.56 & High \\
\hline 5 & I encourage school staff in to take advantage of the knowledge available at school & 4.64 & 0.53 & High \\
\hline 4 & I employ different methods to transfer knowledge & 4.38 & 0.65 & High \\
\hline 3 & I interpret the power of knowledge to operations that can be executed at school & 4.37 & 0.62 & High \\
\hline \multirow[t]{2}{*}{6} & I train the school staff on using and employing knowledge & 4.27 & 0.73 & High \\
\hline & The field as a whole & 4.52 & 0.41 & High \\
\hline
\end{tabular}

*The highest value is 5 .

It is clear from Table 5 that the arithmetic means for the items of the field "transferring and using knowledge" ranged between 4.27-4.75. The highest value was for item number 1 "I provide knowledge to all staff working in the school" with a standard deviation 4.75. Item number 2 "I provide a supportive climate for exchanging knowledge among school staff" came second with arithmetic mean of 4.67 with a standard deviation 0.56 . The lowest arithmetic mean value was for item number 6 "I train the school staff on using and employing knowledge" with a standard deviation $(0.73)$.

To answer the second question: What is the effectiveness level of administrative decisions made by school principals in Ma'an Governorate? The arithmetic means and standard deviations of the study sample estimates for each item of the scale, and for the scale as a whole, as described in Table 6.

Table 6. The arithmetic means and standard deviations for the respondents' estimates regarding the field: "the effectiveness level of administrative decision-making" in descending order

\begin{tabular}{llccc}
\hline No. & Item & $\begin{array}{c}\text { Arithmetic } \\
\text { Mean * }\end{array}$ & $\begin{array}{c}\text { Standard } \\
\text { Deviation }\end{array}$ & $\begin{array}{c}\text { Agreement } \\
\text { degree }\end{array}$ \\
\hline 7 & I explain the content of the decision in order to be implemented properly & 4.62 & 0.55 & High \\
1 & I make decisions in light of study and meticulous information & 4.57 & 0.59 & High \\
9 & I employ appropriate means of communication for announcing decisions & 4.55 & 0.62 & High \\
4 & I declare all decisions made within the school & 4.53 & 0.69 & High \\
\hline
\end{tabular}




\begin{tabular}{|c|c|c|c|c|}
\hline 6 & I notice the impact of the decision on the school staff & 4.51 & 0.64 & High \\
\hline 2 & I follow the results of implementing decisions so as not to deviate from the target & 4.44 & 0.63 & High \\
\hline 10 & I take actions against staff who fail to implement the decision & 4.43 & 0.67 & High \\
\hline 3 & I share decision-making with all parties concerned & 4.42 & 0.67 & High \\
\hline 8 & I provide a feedback system for decisions taken & 4.37 & 0.67 & High \\
\hline \multirow[t]{2}{*}{5} & I share the authority of decision-making with staff & 4.33 & 0.76 & High \\
\hline & The field as a whole & 4.48 & 0.43 & High \\
\hline
\end{tabular}

*The highest value is 5 .

Table 6 shows that the arithmetic means for the field "the effectiveness level of administrative decision-making" ranged between 4.33-4.62. The highest value was for item number 7 "I explain the content of the decision in order to be implemented properly" with a standard deviation 0.55 . Item number 1 "I make decisions in light of study and meticulous information" came second with arithmetic mean of 4.57 with a standard deviation 0.59 . The lowest arithmetic mean value was for item number 5 "I share the authority of decision-making with staff" with a standard deviation 0.76 .

To answer the third question: Is there a statistically significant relationship at the level $(\alpha=0.05)$ between the arithmetic means of the study sample estimations regarding practicing knowledge management by school principals in Ma'an Governorate and their estimations regarding the effectiveness of administrative decisions made by the principals? We calculated Pearson's correlation coefficient between the level of practicing knowledge management and the effectiveness level of administrative decisions made by the principals, as shown in Table 7.

Table 7. The arithmetic means and standard deviations for the respondents' estimates regarding the field: "the effectiveness level of administrative decision-making" in descending order

\begin{tabular}{ccccc}
\hline $\begin{array}{c}\text { The Value of Pearson's correlation } \\
\text { coefficient }\end{array}$ & $\begin{array}{c}\text { Knowledge acquisition } \\
\text { and development }\end{array}$ & $\begin{array}{c}\text { Organizing and } \\
\text { assessing knowledge }\end{array}$ & $\begin{array}{c}\text { Transferring and using } \\
\text { knowledge }\end{array}$ & $\begin{array}{c}\text { The scale as a } \\
\text { whole }\end{array}$ \\
\hline $\begin{array}{l}\text { The effectiveness level of } \\
\text { administrative decision-making }\end{array}$ & $0.63^{*}$ & $0.70^{*}$ & $0.65^{*}$ \\
\hline
\end{tabular}

*Statistically significant at the level $\alpha=0.05$.

Table 7 shows the following:

- There is a statistically significant relationship at the level of $(\alpha=0.05)$ between the effectiveness level of administrative decision-making and the level of knowledge acquisition and development, where the value of Pearson's correlation coefficient was 0.63 .

- There is a statistically significant relationship at the level of $\alpha=0.05$ between the effectiveness level of administrative decision-making and the level of organizing and assessing knowledge, where the value of Pearson's correlation coefficient was 0.70 .

- There is a statistically significant relationship at the level of $\alpha=0.05$ between the effectiveness level of administrative decision-making and the level of transferring and using knowledge, where the value of Pearson's correlation coefficient was 0.65 .

To answer the fourth question: Are there any statistically significant differences at the level $(\alpha=0.05)$ between the arithmetic means of the study sample estimations regarding practicing knowledge management by school principals in Ma'an Governorate attributed to the variables (gender, educational qualification, and administrative experience)? The arithmetic means and standard deviations of the study sample estimates regarding the study fields were calculated according to the study variables, as follows:

1) According to the "gender" variable 
Table 8. The arithmetic means and standard deviations of the respondents estimates regarding the study fields according to the "gender" variable

\begin{tabular}{lcccc}
\hline \multicolumn{1}{c}{ Male } & & & Female \\
& & & (80) \\
\hline Study Field & Arithmetic mean & $\begin{array}{c}\text { Standard } \\
\text { deviation }\end{array}$ & Arithmetic & $\begin{array}{c}\text { Standard } \\
\text { deviation }\end{array}$ \\
\hline Knowledge acquisition and development & & 0.41 & 4.34 & 0.39 \\
Organizing and assessing knowledge & 4.20 & 0.56 & 4.34 & 0.41 \\
Transferring and using knowledge & 4.18 & 0.41 & 4.58 & 0.40 \\
Fields as a whole & 4.40 & 0.42 & 4.39 & 0.33 \\
\hline
\end{tabular}

\section{2) According to educational level}

Table 9. The arithmetic means and standard deviations of the respondents estimates regarding the study fields according to the "educational level" variable

\begin{tabular}{|c|c|c|c|c|c|c|c|c|c|c|}
\hline \multirow[b]{2}{*}{ Study Field } & \multicolumn{2}{|c|}{$\begin{array}{c}\text { Bachelor } \\
\text { (28) }\end{array}$} & \multicolumn{2}{|c|}{$\begin{array}{c}\text { High Diploma } \\
\text { (66) }\end{array}$} & \multicolumn{2}{|c|}{$\begin{array}{c}\text { Master degree } \\
\text { (18) }\end{array}$} & \multicolumn{2}{|c|}{$\begin{array}{c}\text { Doctoral degree } \\
\text { (2) }\end{array}$} & \multicolumn{2}{|c|}{$\begin{array}{c}\text { Diploma } \\
\text { (6) }\end{array}$} \\
\hline & $\begin{array}{c}\text { Arithmetical } \\
\text { mean }\end{array}$ & $\begin{array}{l}\text { Standard } \\
\text { deviation }\end{array}$ & $\begin{array}{c}\text { Arithmetical } \\
\text { mean }\end{array}$ & $\begin{array}{l}\text { Standard } \\
\text { deviation }\end{array}$ & $\begin{array}{c}\text { Arithmetical } \\
\text { mean }\end{array}$ & $\begin{array}{l}\text { Standard } \\
\text { deviation }\end{array}$ & $\begin{array}{c}\text { Arithmetical } \\
\text { mean }\end{array}$ & $\begin{array}{l}\text { Standard } \\
\text { deviation }\end{array}$ & $\begin{array}{c}\text { Arithmetical } \\
\text { mean }\end{array}$ & $\begin{array}{c}\text { Standard } \\
\text { deviation }\end{array}$ \\
\hline $\begin{array}{l}\text { Knowledge } \\
\text { acquisition and } \\
\text { development }\end{array}$ & 4.31 & 0.29 & 4.18 & 0.38 & 4.0 & 0.52 & 4.04 & 0.56 & 4.21 & 0.29 \\
\hline $\begin{array}{l}\text { Transferring } \\
\text { and using } \\
\text { knowledge }\end{array}$ & 4.39 & 0.34 & 4.07 & 0.61 & 4.43 & 0.44 & 4.51 & 0.38 & 4.17 & 0.24 \\
\hline
\end{tabular}

\section{3) According to administrative experience}

Table 10. The arithmetic means and standard deviations of the respondents' estimates regarding the study fields according to the "years of administrative experience" variable

$$
\text { Less than } 5 \text { years }
$$

(28)

\begin{tabular}{lcccccc} 
Study Field & $\begin{array}{c}\text { Arithmetic } \\
\text { mean }\end{array}$ & $\begin{array}{c}\text { Standard } \\
\text { deviation }\end{array}$ & $\begin{array}{c}\text { Arithmetic } \\
\text { mean }\end{array}$ & $\begin{array}{c}\text { Standard } \\
\text { deviation }\end{array}$ & $\begin{array}{c}\text { Arithmetic } \\
\text { mean }\end{array}$ & $\begin{array}{c}\text { Standard } \\
\text { deviation }\end{array}$ \\
\hline Knowledge acquisition and development. & 4.28 & 0.41 & 3.82 & 0.49 & 4.15 & 0.46 \\
Organizing and assessing knowledge. & 4.30 & 0.44 & 4.08 & 0.48 & 3.99 & 0.40 \\
Transferring and using knowledge & 4.50 & 0.43 & 4.350 & 0.41 & 4.27 & 0.57 \\
Fields as a whole & 4.33 & 0.36 & 4.02 & 0.39 & 4.12 & 0.35 \\
\hline
\end{tabular}

$$
\text { From 5-10 years }
$$$$
\text { (41) }
$$

(51)

More than 10 years 
The Tables 8-10 show the presence of differences between the arithmetic means of the respondents estimates regarding the study fields according to the study variables gender, educational level, and years of administrative experience. To determine the significance levels of the statistical differences, the Multivariate Analysis of Variance (MANOVA) was used, as shown in Table 11.

Table 11. The results summary of (MANOVA) for the significance of differences between the arithmetic means according to the study variables

\begin{tabular}{|c|c|c|c|c|c|c|c|}
\hline Variation source & & Field & $\begin{array}{c}\text { Squares } \\
\text { total }\end{array}$ & $\begin{array}{c}\text { Degree of } \\
\text { freedom }\end{array}$ & $\begin{array}{c}\text { Mean } \\
\text { Squares }\end{array}$ & F-value & $\begin{array}{l}\text { Significance } \\
\text { level }\end{array}$ \\
\hline \multirow[t]{3}{*}{ Gender } & $\begin{array}{l}\text { Knowledge } \\
\text { development }\end{array}$ & acquisition and & 0.416 & 1 & 0.416 & 2.586 & 0.111 \\
\hline & $\begin{array}{l}\text { Organizing } \\
\text { knowledge }\end{array}$ & and assessing & 0.552 & 1 & 0.552 & 2.465 & 0.119 \\
\hline & $\begin{array}{l}\text { Transferring } \\
\text { knowledge }\end{array}$ & and using & 0.434 & 1 & 0.434 & 2.720 & 0.102 \\
\hline \multirow[t]{3}{*}{ Educational level } & $\begin{array}{l}\text { Knowledge } \\
\text { development }\end{array}$ & acquisition and & 1.122 & 4 & 0.280 & 1.354 & 0.254 \\
\hline & $\begin{array}{l}\text { Organizing } \\
\text { knowledge }\end{array}$ & and assessing & 786.0 & 4 & 0.197 & 0.859 & 0.491 \\
\hline & $\begin{array}{l}\text { Transferring } \\
\text { knowledge }\end{array}$ & and using & 3.688 & 4 & 0.922 & 4.333 & 0.003 \\
\hline \multirow{3}{*}{$\begin{array}{c}\text { Years of } \\
\text { administrative } \\
\text { experience }\end{array}$} & $\begin{array}{l}\text { Knowledge } \\
\text { development }\end{array}$ & acquisition and & 4.171 & 2 & 2.085 & 10.068 & 0.000 \\
\hline & $\begin{array}{l}\text { Organizing } \\
\text { knowledge }\end{array}$ & and assessing & 1.887 & 2 & 0.943 & 4.122 & 0.019 \\
\hline & $\begin{array}{l}\text { Transferring } \\
\text { knowledge }\end{array}$ & and using & 1.368 & 2 & 0.684 & 3.21 & 0.044 \\
\hline \multirow[t]{3}{*}{ Error } & $\begin{array}{l}\text { Knowledge } \\
\text { development }\end{array}$ & acquisition and & 23.405 & 112 & & & \\
\hline & $\begin{array}{l}\text { Organizing } \\
\text { knowledge }\end{array}$ & and assessing & 25.859 & 112 & & & \\
\hline & $\begin{array}{l}\text { Transferring } \\
\text { knowledge }\end{array}$ & and using & 24.046 & 112 & & & \\
\hline
\end{tabular}

*Statistically significant at $\alpha=0.05$.

Table 11 shows that there are no statistically significant differences between the arithmetic means of the respondents regarding the field "practicing knowledge management" attributed to the (gender) variable; the fields "knowledge acquisition and development" and "organizing and assessing knowledge" attributed to the (educational experience) variable. Moreover, the table shows that there are statistically significant differences at the field "transferring and using knowledge" attributed to the (educational level) variable; and at all fields attributed to the (administrative experience) variable. In order to determine the sources of those differences Scheffe's Test was used as shown in Table 12. 
Table 12. The results of applying Scheffe's Test for the post hoc comparisons to the field "transferring and using knowledge" according to the (educational level) variable

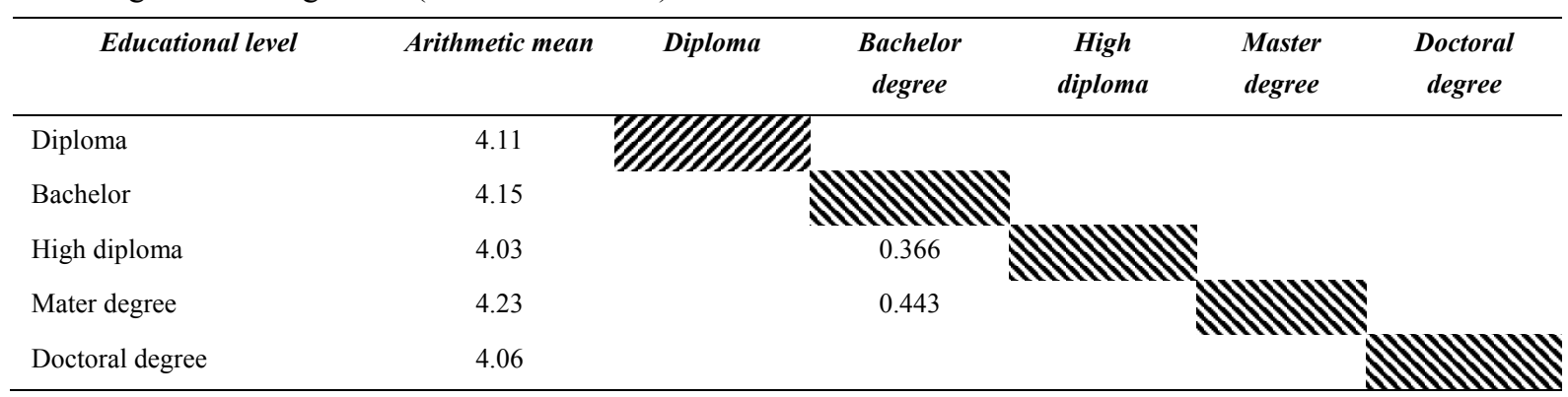

*Statistically significant at $\alpha=0.05$.

We can see from Table 12 we see that there are statistically significant differences between the arithmetic means of (High Diploma) estimates on one side, and the arithmetic means of (Bachelor) estimates on the other side, regarding the field "transferring and using knowledge"; in favor of the (High Diploma). The same goes for (Bachelor degree) estimates on one side and (Master degree) estimates on the other side in favor of the (Master degree).

Table 13. Results of applying Scheffe's test for the post hoc comparisons to the study fields, according to the (administrative experience) variable

\begin{tabular}{lccc}
\hline \multicolumn{1}{c}{ Adm. experience } & Arithmetic mean & Less than 5 years & Fore than 10 \\
years
\end{tabular}

Table 13 shows that there are statistically significant differences between the arithmetic means of less than 5 years estimates on one side, and the arithmetic means of from 5-10 years estimates on the other side, regarding the field "organizing and assessing knowledge" in favor of less than 5 years. And, there are statistically significant differences between the 5-10 years estimates and more than 10 years estimates in favor of more than 10 years. Moreover, there were differences regarding the field "transferring and using knowledge" between the (less than 5 years) estimates and (more than 10 years) estimates in favor of (less than 5 years).

To answer the fifth question: Are there any statistically significant differences at the level $(\boldsymbol{\alpha}=\mathbf{0 . 0 5})$ between the arithmetic means of the study sample estimations regarding the effectiveness of administrative decisions made by school principals in Ma'an Governorate attributed to the variables (gender, educational qualification, and administrative experience)? We calculated the arithmetic means and standard deviations of 
the respondents' estimates regarding the effectiveness level of administrative decision-making; according to the study variables, as follows:

\section{1) According to ( gender) variable}

Table 14. The arithmetic means and standard deviations of the respondents' estimates regarding the effectiveness level according to the (gender) variable

\begin{tabular}{|c|c|c|c|c|}
\hline \multirow[b]{2}{*}{ Field } & \multicolumn{2}{|c|}{$\begin{array}{c}\text { Male } \\
\text { (40) }\end{array}$} & \multicolumn{2}{|c|}{$\begin{array}{c}\text { Female } \\
\text { (80) }\end{array}$} \\
\hline & $\begin{array}{c}\text { Arithmetic } \\
\text { mean }\end{array}$ & $\begin{array}{c}\text { Standard } \\
\text { deviation }\end{array}$ & $\begin{array}{c}\text { Arithmetic } \\
\text { mean }\end{array}$ & $\begin{array}{c}\text { Standard } \\
\text { deviation }\end{array}$ \\
\hline Effectiveness level of administrative decision-making & 4.38 & 0.42 & 4.25 & 0.42 \\
\hline
\end{tabular}

\section{2) According to (educational level) variable}

Table 15. The arithmetic means and standard deviations of the respondents' estimates regarding the effectiveness level according to the (educational level) variable

\begin{tabular}{|c|c|c|c|c|c|c|c|c|c|c|}
\hline \multirow[b]{3}{*}{ Filed } & \multirow{2}{*}{\multicolumn{2}{|c|}{$\begin{array}{c}\text { Diploma } \\
6\end{array}$}} & \multirow{2}{*}{\multicolumn{2}{|c|}{$\begin{array}{c}\text { Bachelor degree } \\
28\end{array}$}} & \multirow{2}{*}{\multicolumn{2}{|c|}{$\begin{array}{c}\text { High Diploma } \\
66\end{array}$}} & \multirow{2}{*}{\multicolumn{2}{|c|}{$\begin{array}{c}\text { Master degree } \\
18\end{array}$}} & \multirow{2}{*}{\multicolumn{2}{|c|}{$\begin{array}{c}\text { Doctoral degree } \\
2\end{array}$}} \\
\hline & & & & & & & & & & \\
\hline & $\begin{array}{c}\text { Arithmetic } \\
\text { mean }\end{array}$ & $\begin{array}{l}\text { Standard } \\
\text { deviation }\end{array}$ & $\begin{array}{c}\text { Arithmetic } \\
\text { mean }\end{array}$ & $\begin{array}{l}\text { Standard } \\
\text { deviation }\end{array}$ & $\begin{array}{c}\text { Arithmetic } \\
\text { mean }\end{array}$ & $\begin{array}{l}\text { Standard } \\
\text { deviation }\end{array}$ & $\begin{array}{c}\text { Arithmetic } \\
\text { mean }\end{array}$ & $\begin{array}{l}\text { Standard } \\
\text { deviation }\end{array}$ & $\begin{array}{c}\text { Arithmetic } \\
\text { mean }\end{array}$ & $\begin{array}{l}\text { Standard } \\
\text { deviation }\end{array}$ \\
\hline $\begin{array}{l}\text { Effectiveness } \\
\text { level of } \\
\text { administrative } \\
\text { decision-making }\end{array}$ & 4.28 & 0.38 & 4.41 & 0.44 & 4.53 & 0.41 & 4.48 & 0.46 & 4.00 & 00.0 \\
\hline
\end{tabular}

\section{3) According to changes of Adm. experience}

Table 16. The arithmetic means and standard deviations of the respondents' estimates regarding the effectiveness level according to the (administrative experience) variable

\begin{tabular}{|c|c|c|c|c|c|c|}
\hline \multirow[b]{3}{*}{ Filed } & \multirow{2}{*}{\multicolumn{2}{|c|}{$\begin{array}{l}\text { Less than } 5 \text { years } \\
\qquad 22\end{array}$}} & \multirow{2}{*}{\multicolumn{2}{|c|}{$\begin{array}{c}\text { From 5-10 years } \\
41\end{array}$}} & \multirow{2}{*}{\multicolumn{2}{|c|}{$\begin{array}{l}\text { Less than } 10 \text { years } \\
\qquad 51\end{array}$}} \\
\hline & & & & & & \\
\hline & $\begin{array}{l}\text { Arithmetic } \\
\text { mean }\end{array}$ & $\begin{array}{l}\text { Standard } \\
\text { deviation }\end{array}$ & $\begin{array}{l}\text { Arithmetic } \\
\text { mean }\end{array}$ & $\begin{array}{l}\text { Standard } \\
\text { deviation }\end{array}$ & $\begin{array}{l}\text { Arithmetic } \\
\text { mean }\end{array}$ & $\begin{array}{l}\text { Standard } \\
\text { deviation }\end{array}$ \\
\hline $\begin{array}{l}\text { Effectiveness level of administrative } \\
\text { decision-making }\end{array}$ & 4.53 & 0.41 & 4.43 & 0.42 & 4.49 & 0.43 \\
\hline
\end{tabular}

To determine the presence of differences between arithmetical means of the respondents' estimates regarding the effectiveness level of administrative decision-making according to the study variables; the Multivariate Analysis of Variance (MANOVA) was used, as shown in Table 17. 
Table 17. The results summary of (MANOVA) for the significance of differences between the arithmetic means according to the study variables

\begin{tabular}{lccccc}
\hline \multicolumn{1}{c}{ Variable source } & Squares total & Freedom degree & Mean Squares & F-Value & Significance level \\
\hline gender & 0.316 & 1 & 0.316 & 1.763 & 0.187 \\
Educational level & 0.791 & 4 & 0.198 & 1.101 & 0.360 \\
Administrative experience & 0.132 & 2 & 0.066 & 0.369 & 0.692 \\
Error & 20.097 & 112 & 0.179 & \\
\hline
\end{tabular}

We see from Table 17 that there are no statistically significant differences between the arithmetic means of the respondents' estimates attributed to the study variables: gender, educational level, and administrative experience.

\section{Explanation of the Study Results}

- Through the review of the findings on the first question: "What is the level of practicing knowledge management by school principals in Ma'an Governorate?" The arithmetic means of the scale's fields ranged between 4.28-4.52 with a high evaluation degree. This indicates that there is a clear awareness among school principals in $\mathrm{Ma}$ 'an governorate regarding the importance of practicing knowledge in school administration; due to its role in overcoming many problems and challenges facing the school administration. This is attributed to the educational experiences that the school principals have, and the active role of the Ministry of Education in raising awareness of the concepts of knowledge through conducting training courses and lectures presented to school principals.

- The results related to the second question: "What is the effectiveness level of administrative decisions made by school principals in Ma'an Governorate?" show that the arithmetic means of the field "the effectiveness level of administrative decision-making" ranged between 4.33-4.75 with a high evaluation degree. This supports the result of the first question, as the effectiveness of the decision-making relies heavily on the knowledge and its application. A decision cannot be effective without being based on a solid knowledge base. This result implies that the school principals were selected according to specific criteria such as experience and good performance, and this gives the principal a distinct ability to make effective decisions at school.

- The results of the third question: "Is there a statistically significant relationship at the level $(\alpha=0.05)$ between the arithmetic means of the study sample estimations regarding practicing knowledge management by school principals in Ma'an Governorate and their estimations regarding the effectiveness of administrative decisions made by the principals?" showed that there is a statistically significant relationship between the effectiveness level of administrative decision-making on the one hand, and the fields of knowledge management processes on the other hand. This result is logical, as the effective decision is linked to knowledge acquisition, development, organizing, and transfer.

- As for the fourth question: "Are there any statistically significant differences at the level $(\alpha=0.05)$ between the arithmetic means of the study sample estimations regarding practicing knowledge management by school principals in Ma'an Governorate attributed to the variables (gender, educational qualification, and administrative experience)?" The results showed that there are no statistically significant differences between the arithmetic means of the respondents' estimates on the field "practicing knowledge management" attributed to (gender) variable. This can be justified by the fact that the principals of both genders have similar expertise; and, selecting school principals is subjected to a set of standards that are similar for both genders. Moreover, the school principals undergo training programs contribute to the removal of the differences between genders. The results also showed that there are statistically significant differences between the arithmetic means of (High Diploma) estimates on the one hand, and the arithmetic means of (Bachelor) estimates on the other hand, regarding the field "transferring and using knowledge"; in favor of the (High Diploma). The same goes for (Bachelor degree) estimates on the one hand and (Master degree) estimates on the other hand in favor of the (Master degree). This is attributed to the fact that school principals holding high diploma or master degree have received educational habilitation that helped them to be more competent in transferring and using knowledge in school administration.

Furthermore, there were statistically significant differences between the arithmetic means of the respondents' estimates who had less than 5 years experience on the one hand, and the arithmetic means of (from 5-10 years) 
estimates on the other hand, regarding the fields "organizing and assessing knowledge" and "transferring and using knowledge" in favor of less than 5 years. This can be attributed to the fact that school principals who have less than 5 years experience are seeking to develop their performance and be informed of what's new in administration, in order that they could make the appropriate decision in administration. As for those who have more than 10 years of experience, we can see the impact of the experience that contributes to the development of performance and efficiency of school principals, and help them in the organizing and transferring knowledge.

- As for the fifth question: "Are there any statistically significant differences at the level $(\alpha=0.05)$ between the arithmetic means of the study sample estimations regarding the effectiveness of administrative decisions made by school principals in Ma'an Governorate attributed to the variables (gender, educational qualification, and administrative experience)?" The results showed that there are no statistically significant differences between the arithmetic means of the respondents' estimates regarding "the effectiveness of administrative decision-making" according to the study variables: gender, educational level, and administrative experience. This may be attributed to the fact that school principals have similar professional qualities.

\section{Recommendations}

In light of the results that have been reached, the researchers recommend the following:

- Taking advantage of the qualified personnel at the education directorates to train principals on knowledge management processes.

- Expanding the use of modern communication systems and opening communication channels between the schools, the departments of education, and the Ministry of Education.

- Establishing an electronic portal for each school for easy exchange of knowledge with other schools.

- Establishing "Knowledge Management Unit" at the Ministry of Education and the departments of Education.

- Forming a committee within each school dealing with the issue of knowledge management.

\section{References}

Al Bilawi, H. S. (2007). Knowledge Management in Education. Dar Al-Wafa, Alexandria, Egypt.

Al Naji, M. (2011). Education and School Management. Dar Al Kutob, Jeddah, Saudi Arabia.

Al-Ali, A. (2006). An Approach to Knowledge Management. Dar Al-Maseera for Publishing, Dstribution, and Printing, Amman, Jordan.

Al-Khalili, S. (2006). Knowledge Management at the Ministry of Education (Unpublished Master Thesis). Yarmouk University, Irbid, Jordan.

Al-Kubaisi, S., \& Khudair, F. (2004). Knowledge Management. Arab Institution for Administration, Cairo.

Al-Sawi, Y. (2007). Knowledge Management and Information Technology. Al-Sahab for Publishing and Distribution, Cairo, Egypt.

Al-Taweel, H. (2006). Scientific Management: Concepts and Horizons. Wael for Publishing and Distribution, Amman, Jordan.

Al-Thubaiti, J. (2002). Knowledge Management and Investment in Knowledge Capital and Universities. Journal of Education and Development, 26, 38.

Aqeeli, O. (2005). Modern Management of Human Resources: Strategic Dimension. Wael for Publishing and Distribution, Amman, Jordan.

Glickman, B. (2004). What Counts: Education Knowledge Management Practices (Unpublished Dissertation). The University of British Columbia (Canada).

Hansen et al. (1999). What's Your Strategy for Managing Knowledge? In Business Review: Harvard (pp. 61-106).

Holsapple, C., \& Singh, M. (2001). The Knowledge Chain Model: Activities for Competitiveness. Expert Systems with Applications, 20(1), 77-98. https://doi.org/10.1016/S0957-4174(00)00050-6 
Keeley, A. (2004). Institutional Study as the Catalyst for the Extent and Effectiveness of Knowledge Management Practices in Improving Planning and Decision Making in Higher Education Organizations. U.S.A. Retrieved from http//www.proquest.com/pqdweb

Kim, S., \& Mitchell, R. (2004). Building a Knowledge Model: A Decision-making Approach. Journal of Knowledge Management Practice, 5(1), 68-75.

Ma'ayah, A. (2008). Knowledge and Information Management at Higher Education Institutions: Universal Experiences. Journal of Information Study.

Newton, T. (2001). Organizational Study (Vol. 8, No. 3, pp. 459-465).

Talha, A. (2005). Public Institutions Administration in the Developing Countries. Al-Hamed for Publishing and Distribution, Amman, Jordan.

Tashkandi, Z. (2006). Knowledge Management: Importance and Practice (Unpublished Master Thesis). Um Al Qura University, Mecca, Saudi Arabia.

York, P. (2005). Knowledge Management. Longman for Publications, Cairo.

Zerger, B. (1998). Art of Knowledge Management (p. 17).

\section{Copyrights}

Copyright for this article is retained by the author(s), with first publication rights granted to the journal.

This is an open-access article distributed under the terms and conditions of the Creative Commons Attribution license (http://creativecommons.org/licenses/by/4.0/). 